American Medical Journal 2 (1): 1-6, 2011

ISSN 1949-0070

C 2011 Science Publications

\title{
Estimation of Pathogenic Microorganisms during Atmospheric Tempestat North Africa
}

\author{
U. Ali Rahoma \\ Department of Medical Radiology, Faculty of Medical Technology, \\ Omer El-Mukhtar University, Tobruk, Libya
}

\begin{abstract}
Problem statement: Dust continued to blow across northern Africa and the Mediterranean Sea on March 3, 2005. Many sources are associated with areas where human impacts are well documented. Approach: Nonetheless, the largest and most active sources are located in truly remote areas where there is little or no human activity. Dust activity is extremely sensitive to many environmental parameters. Results: The persistent sources are located in the Northern Hemisphere, mainly in a broad "dust belt" that extends from the Meddle coast of North Africa over the Middle East. In this study we identify local environments enables us to identify those characteristics that are important for dust generation. However, if dust has an impact on climate, then the role of humans in the destabilization of soil surfaces takes on an added dimension. Conclusion/Recommendations: Threshold effects may be at work. Human health may also be adversely affected, primarily by inhalation of known or suspected components in dust events, including nonpathogenic and pathogenic viable microorganisms; chemical contaminants such as carcinogens, toxins, endocrine disruptors and toxic metals and small particles that may trigger other physiological reactions (e.g., asthma, cardiovascular events).
\end{abstract}

Key words: Chemical contaminants, human health, dust activity, toxic metals, aureobasidium, moderate resolution, spectroradio meter, pseudomonas, Absorbing Aerosol Index (AAI)

\section{INTRODUCTION}

Every human breath taken is laden with particulate matter and human evolution produced the most obvious and familiar front line of defense, nose hair. Less obvious are the mucus glands that line our airways. These glands function to trap and aid in the expulsion of particulates via secretion, ciliated transport and ingestion or cough. Of particular concern are particles of $<10 \mu \mathrm{m}$ in size that can penetrate into the lungs and those of $<2.5 \mu \mathrm{m}$ that may penetrate into deep lung tissue and the subepithelial environment. These very small particles cause adverse health effects via oxidative stress. The deposition rate of ultrafine particles $(<100 \mathrm{~nm})$ in the lungs has been shown to increase as particle size decreases and to increase with exercise versus resting Wurzler et al., 2000. Health studies conducted in urban and suburban environments have demonstrated mortality risk with exposure to particulate matter and have attributed this risk to anthropogenic particulates generated through automotive and industrial combustion versus those of crustal origin (Dickerson et al., 1997). Several studies conducted to investigate the role of dust storms that consist of concentrated crustal particulates have shown an associated allergic, asthma and silicosis/pulmonary fibrosis risk. Areas impacted by desert dust storms, such as communities in the Middle East and the Caribbean, are known to have some of the highest incidences of asthma on the planet (Karami et al., 2009). Important role in climate forcing by altering the radiation balance in the atmosphere through the scattering and absorption of radiation (Tegen et al., 1997; Haywood and Boucher, 2000; Harrison et al., 2001). Mineral dust could also affect climate indirectly by affecting cloud nucleation and optical properties (Levin et al., 1996; Wurzler et al., 2000). In addition, dust can serve as a reaction surface for reactive gas species in the atmosphere (Dentener et al., 1996) and for moderating photochemical processes. Mineral dust is believed to play an important role in many marine biogeochemical processes. Similarly, many studies have characterized dust generation on a micrometeorological scale (Gillette, 1999, Jamal et al., 2005). Although these patterns may change seasonally, sometimes disappearing during some seasons, they appear year after year.

\section{MATERIALS AND METHODS}

Air samples for isolation of microbes: Presterilized filter housings containing $47 \mathrm{~mm}$ diameter, $0.2 \mu \mathrm{m}$ 
pore-size filter membranes were used to collect all air samples (Fisher Scientific, Atlanta, GA.). The filter housings were removed from their respective sterile bags, placed on an analytical filter manifold, lids removed and vacuum applied using a vacuum pump for a set period of time. Airflow rates through the filters ranged from 6.5-28.4 $\mathrm{L} \mathrm{min}^{-1}$ for 8-20 min per sample. To control for handling contamination, an additional filter housing was removed from its bag, placed on the manifold and allowed to sit for one-minute without removing the lid or turning on the vacuum. Filter housings were then removed from the manifold, lids sealed with parafilm, replaced in their respective bags, sealed with tape and either transported to the ship laboratory or for the USVI samples. The sample filters were either placed whole or cut in half using sterile scissors and one half of the filter placed on R2A agar plates, sample side up. The remaining halves of cut filters were stored via refrigeration at $4^{\circ} \mathrm{C}$. The filters placed on R2A were incubated in the dark at room temperature $\left(23^{\circ} \mathrm{C}\right)$ and monitored for growth over a 48 $\mathrm{h}$ period. Fungal and bacterial colonies were isolated from each other by isolation streaking on to fresh plates of R2A. Once isolated, colonies were grown overnight at room temperature on a tabletop rocker set at low speed in Tryptic Soy Broth (Fisher Scientific, Atlanta, GA.). The following day $1 \mathrm{~mL}$ of each culture was transferred to a sterile cryogenic storage tube containing $200 \mu \mathrm{L}$ of sterile glycerol. Procedure analysis is treatment inside the Lab. Of El-Batnan Center for medicine works.

Throughout this study, we identify the location of active source regions and discuss the factors that might make them good sources of mineral dust. Our analyses are mostly based on FOO distributions as shown in the previous examples.

\section{RESULTS}

Characterization of dust at North Africa: The objective of this study was to identify relatively strong and persistent dust sources so as to be able In July the large dark area in southern Africa is due to biomass burning. In January, there is biomass burning in the region just north of the equator in Africa; part of the plume over the equatorial ocean is due to smoke. Essentially, all other distributions in Fig. 1: shows the global FOO distribution of absorbing aerosol for January and July based on TOMS analysis of daily TOMS AAI values $>7$ for the period 1980-2001 (Torres et al., 2002, El Dawi et al., 2004).
In North Africa the maximum dust transport occurs in summer when large quantities of dust are carried across the Mediterranean to Europe and the Middle East (Vernooy et al., 2002). Dust activity is at a minimum in the fall. The locus of dust activity shifts with the season.

In North Africa the winter dust activity is greatest in the low latitudes; as the year progresses, dust activity moves to the higher latitudes. In the Middle East, activity peaks in the late spring and summer and is at a minimum in the winter. Over the Indian subcontinent, activity peaks in the spring and decreases the southeast monsoon.

Dust storm sources of North Africa: Eastern Libyan Desert; Libya is an oil exporting country located in the middle of North Africa, with 6 million inhabitants distributed over an area of $1,750,000 \mathrm{Km}^{2}$. The daily average of solar radiation on a horizontal plane is 7.1 $\mathrm{kWh} \mathrm{m}^{-2}$ day $^{-1}$ in the coastal region and $8.1 \mathrm{kWh} \mathrm{m}^{-1}$ day $^{-1}$ in the southern region, with average sun duration of more than $3500 \mathrm{~h}_{\text {year }}{ }^{-1}$.

The national electric grid consists of a high voltage network of about $12,000 \mathrm{~km}$, a medium voltage network of about $12,500 \mathrm{~km}$ and $7,000 \mathrm{~km}$ of low voltage network. The installed capacity is $5600 \mathrm{MW}$ with a peak Load of 3650 MW, for the year 2004.

In spite of that; there are many villages and remote areas located far away from these net-works. Economically these areas cannot be connected to the grid, owing to its small population and small amount of energy required. In the past these facts dictate the use of diesel generators as a power supply. A large area of dust activity extends over the eastern Libyan desert into western Egypt.

These sources are active during much of the year. Activity is most intense in May-June. The northern part of this feature lies over a low-lying region that is marked with a number of drainage features, in particular, a chain of wadis (Wadi al-Farigh and Wadi al Hamim) which receive flow from the somewhat elevated coastal region to the north (the Al Jabar al Akhdar hill range in Libya. The wadi system (and associated complexes of salt/dry lakes) extends from the Libyan coast on the Gulf of Sidra south of Banghazi (Benghazi) to the Qattara Depression, the white area near $30^{\circ} \mathrm{N}, 28^{\circ} \mathrm{E}$ ). In this study we will show that wadis (an ephemerally wet valley, gully, or streambed) are a common feature in many TOMS sources along with alluvial fans and playas. The eastern extreme of the dust source is located over the southwestern end of the Qattara Depression. 


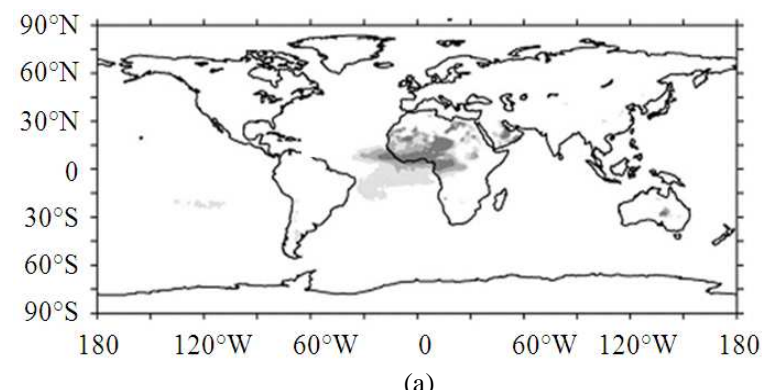

(a)
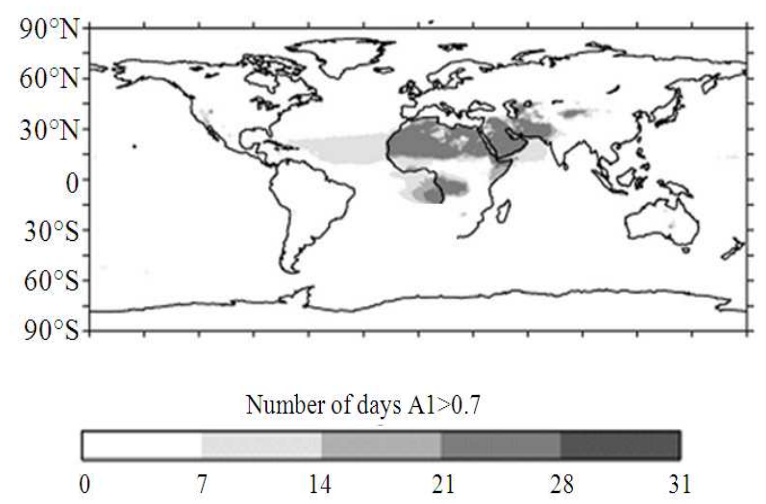

(b)

Fig. 1: Global distributions of dust and smoke: monthly frequency of occurrence of TOMS absorbing aerosol product over the period 1980-2001. (a) January; (b) July. Scale is number of days per month when the Absorbing Aerosol Index (AAI) equals or exceeds 0.7

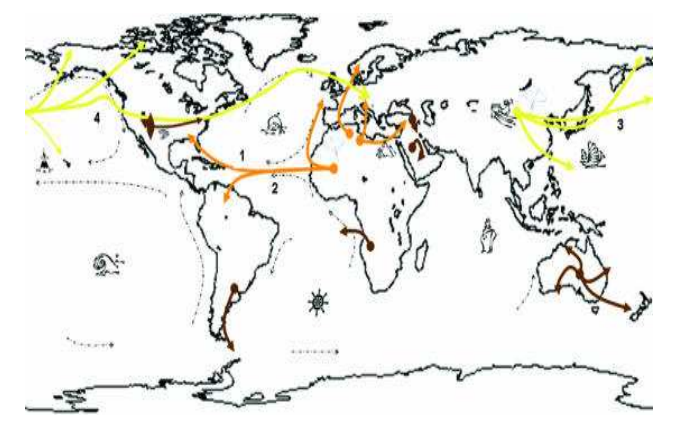

Fig. 2: Primary sources of desert dust and their atmospheric pathways

During summer in the Northern Hemisphere (approximately June through October), African desert dust is transported across the Atlantic to the northern Caribbean and North America. During winter in the Northern Hemisphere (approximately November through May), African desert dust is transported across the Atlantic to the southern Caribbean and South America. (Base map image courtesy of NASA's
Geospatial Interoperability Office, GSFC [http://viewer.digitalearth.gov/].

The active region extends in a relatively narrow corridor to the southwest to $22^{\circ}-23^{\circ} \mathrm{N}, 15^{\circ} 17^{\circ} \mathrm{E}$, bounded on the west by the Al-Haruj al-Aswad hill range (maximum altitude $1200 \mathrm{~m}$ ) and the Jabal Bin Ghunaymah mountains and the Sarir Tibasti highlands on the border with Chad.

Dust emanates from North Africa year-round and at times throughout the year impacts air quality in Africa, the Middle East, Europe, Asia, the Caribbean and the Americas (Fig. 2). Dust source areas in the Sahara and Sahel, primary latitudinal transport routes and the influence of climate and climate systems (North Atlantic Oscillation and El Niño, etc.) on year-to-year dust flux have been previously reported Goudie and Middleton, 2001 and Tucker and Nicholson, 1999).

Egypt: The Egyptian sources become active in March and cease about October (Fig. 1). The most active area is roughly oriented NW-SE with southeastern most extension at $24^{\circ}-25^{\circ} \mathrm{N}, 33^{\circ} \mathrm{E}$, a little north of Aswan and the northwestern extension at $27^{\circ} \mathrm{N}, 29^{\circ} \mathrm{E}$. As the dust season progresses, the TOMS distribution extends to the northwest and merges with the previously described Libyan source in the southwest of the Qattara Depression. The eastern boundary of the dust activity is largely defined by the west bank of the Nile. The western limit is in the low lying area in central Egypt, which is the location of a series of north-south trending escarpments, depressions (Kharga, Dakhla, Farafra and Bahariya) and associated oases and the only major road in the interior. The dust source lies over a region marked in some maps as the Gurd Abu Muharrik, which does not have any major dune systems. In contrast, TOMS shows no major dust sources over the Great Sand Sea in the Western Desert. The Mediterranean is frequently impacted by dust storms in the late spring and summer (Moulin et al., 1998; Guerzoni and Chester, 1996). The TOMS data suggest that the principal sources of the dust are most likely the regions described here in eastern Algeria, Tunisia, Libya and Egypt. The association of dust sources with water features is paradoxical but nonetheless consistent with our understanding of the processes involved in the production of fine particles through weathering.

Fluvial and chemical weathering processes are much more efficient in the production of small particles (i.e., particles less than $\sim 10 \mu \mathrm{m}$ diameter) than are aeolian processes (i.e., grinding and impaction). 


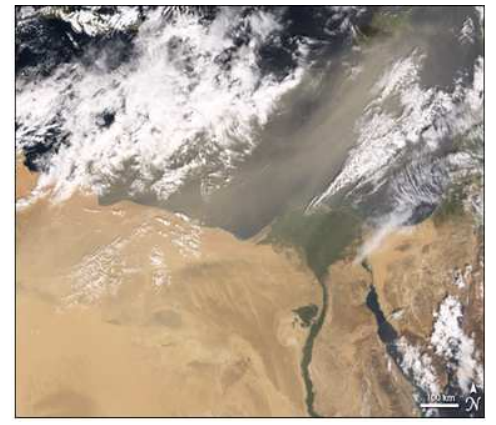

Fig. 3: Dust continued to blow across northern Africa and the Mediterranean Sea on March 3, 2005. In this image from the Moderate Resolution Imaging Spectroradiometer (MODIS) on NASA's Terra satellite, dust stretches northeastward from Libya and Egypt all the way to the island of Cyprus (upper right)

Table 1: Isolates identified from an air sample collected on March 3 2005 during a dust event. This sample was collected offshore, Tobruk, Libya

\begin{tabular}{lll}
\hline Microorganism & Classification & Identification \\
\hline Bacillus pumilus & Bacteria gram & +1 \\
Bacillus thuringiensis & Bacteria gram & 4 \\
Microbacterium imperiale & Bacteria gram $^{-1}+$ & 1 \\
Propionibacterium sp. & Bacteria gram & 1 \\
Unknown & Bacteria gram & 1 \\
Aureobasidium sp. & Fungi & 1 \\
Cladosporium sp. & Fungi & 4 \\
Trichophyton sp. & Fungi & 1 \\
\hline
\end{tabular}

Also, through fluvial action, small particles are separated from the soil and rock matrix and carried to depositional basins or alluvial plains where, after drying, they are subject to deflation by wind. Fig. 3: is a In this image from the Moderate Resolution Imaging Spectroradiometer (MODIS) on NASA's Terra satellite, dust stretches northeastward from Libya and Egypt all the way to the island of Cyprus (upper right). The distributions were computed using a threshold of 1.0 in the dust belt and 0.7 everywhere else.

We have noted at another of our field sites that as a dust cloud moves through a region it can leave suspended residual particles such as fine inorganic and microorganisms that typically takes two to three days to clear (manuscript in preparation). This haze was due to high humidity and may have served to keep aerosolized marine microorganisms suspended in the air longer than normal. This may explain the high numbers of grambacteria collected during the two cruise sample periods.

Figure 1 is image of August 8, 2001 and shows dust activity across the tropical Atlantic for that time period. As can be seen in and a number of these bacterial or fungal isolates are closely related to microorganisms typically found in soils or in association with plant life.

This genus of fungi is one of the most frequently recovered in environmental field studies and many species within this genus are pathogens to a wide variety of plants and animals. Table 1 lists data from sample taken during the March 3, 2005 dust event. A total of 9 bacteria $(n=10)$ and 5 . fungi $(n=6)$ were identified from the original sample. All the bacterial colonies recoveredwere gram + bacteria and one of the isolates was Bacillus thuringiensis, a known pathogen of insects. Six of the nine identifiedbacterial colonies were Bacillus sp. The majority of isolated fungi were Cladosporium sp. Other fungi recovered during these sample periods include Aspergillus sp., Acremonium sp., Aureobasidium sp., Bipolaris sp., Microsporium sp., Nigrospora sp., Paecilomyces sp. and Penicillium sp.

Outside of Aspergillus sp., of which 20 are known pathogenic human species, most of the others are usually found in soils or in association with plants and in rare cases may contain species that cause opportunistic human infections.

This data indicates that while collecting airborne microorganisms during African dust events, a few local microorganisms may be collected simultaneously with the foreign flora. Although the field of microbial ecology is limited in its ability to distinguish foreign from local flora, we are currently identifying all cultivable isolates in order to develop a database which in time may allow us to identify regionally specific groups or isolates within pure or mixed samples. The results of the non-dust offshore samples collected during the March 3, 2005. The genus of fungi that was most often recovered was the Trichophyton sp.

Three isolates of Microsporium were isolated during the two cruises, followed by the two colonies of Cladosporium sp. collected on the June cruise. Other fungi collected included Chrysosporium sp., Penicillium sp., Rhizomucor sp., Scytalidium sp. and Trichophyton sp. Of the bacteria collected, isolates of Acinetobacter sp. and Pseudomonas sp. (gram-bacteria) were the most commonly encountered. Species of these two genera are commonly found in aquatic and soil environments and may represent the presence of aerosolized marine organisms moving in the near seasurface atmosphere due to surface activity (sea spray). Bacillus megaterium is a known tree pathogen and one isolate was collected during the July cruise.

The Duganella sp. isolate matched at $99 \%$ sequence similarity to DNA isolated from human tissue during a disease surveillance study. The cruise isolates are predominantly gram-rich in contrast to the predominantly gram + rich late summer USVI isolates. 
As previously stated, the majority of late summer isolates (all of the gram+ isolates) were either high $\mathrm{G}+\mathrm{C}$ content gram + or low $\mathrm{G}+\mathrm{C}$ spore forming gram + . High $\mathrm{G}+\mathrm{C}$ content DNA or the ability to form spores (bacteria and fungi) is traits which impart resistance to UV inactivation. Although a large number of bacteria were of the type typically resistant to UV stress, large fractions $(40 \%)$ were gram-bacteria.

\section{DISCUSSION}

In contrast, TOMS shows that there are dominant sources and that these present a remarkably consistent pattern both from the standpoint of the geometry of the individual sources and the seasonal changes in their shape and distribution.

Most of the prominent sources identified in Fig. 2 is associated with topographical lows or with regions on the flanks of topographical highs. In the latter regard, The Ahaggar and Tibesti Mountains dominate the sources in central North Africa. These mountains are ringed with some of the most active dust sources in North Africa and, indeed, the world. This suggests that weathering processes and runoff from the mountains play an important role in providing fine soil material that can be mobilized as dust.

Similarly, in the north the only place where rainfall exceeds $200-250 \mathrm{~mm}$ is on the northern (Tell) Atlas and along the Mediterranean coast. Thus we conclude that in a broad regional sense, we should not expect to see strong dust sources in regions where rainfall is 200-250 $\mathrm{mm}$. We reach the same conclusion throughout this study in the analysis of the dust sources in other regions. In general, we do not see evidence that the major dune systems and sand seas are persistent sources of dust, although they may be important sources on a sporadic basis. For example, the Erg Chech in southern Algeria and Mauritania, one of the largest sand seas in the world, is not a persistent source (as defined by TOMS); the Great Sand Sea in the Western Desert of Egypt is similar. On the other hand, many of the most active sources are located on the edges of these dune systems, a fact that may be linked to the mechanism of dust generation. Often it is difficult to draw a clear distinction between the dust sources and the dune fields. For example, the core of activity in the Lake Chad basin lies over the Bodele Depression, which itself lies in close association with Erg du Djourab, a major sand sea. Finally, we have noted that many of the intense sources are associated with regions where there are extensive alluvial deposits. These sediments are either discharged through alluvial fans or wadis emanating from proximate highlands or deposited in recent pluvials.

\section{CONCLUSION}

Atmospheric flux of pathogenic microorganisms may be responsible for the widespread distribution of some diseases occurring on coral reefs and associated habitats. Chemical contaminants in dust air masses may alter the resistance of coral reef organisms to disease pathogens, affect reproduction or survival of larvae, interfere with calcification, or act as toxins, initiating a cascade of effects. Episodic pulses of micro- and macronutrients are known to initiate phytoplankton blooms and may similarly trigger pathogen reservoirs or act to sustain the shift from coral- to algae-dominated reefs. Threshold effects may be at work. Human health may also be adversely affected, primarily by inhalation of known or suspected components in dust events, including nonpathogenic and pathogenic viable microorganisms; chemical contaminants such as carcinogens, toxins, endocrine disruptors and toxic metals and small particles that may trigger other physiological reactions (e.g., asthma, cardiovascular events).

\section{REFERENCES}

Dentener, F.J., G.R. Carmichael, Y. Zhang, J. Lelieveld and P.J. Crutzen, 1996. Role of mineral aerosol as a reactive surface in the global troposphere. J. Geophys. Res., 101: 22869-22889. DOI: 10.1029/96JD01818

Dickerson, R.R., S. Kondragunta, G. Stenchikov, K.L. Civerolo and B.G. Doddridge et al., 1997. The impact of aerosols on solar ultraviolet radiation and photochemical smog. Science, 278: 827-830. DOI: $10.1126 /$ science.278.5339.827

El Dawi, M.G., L. Tianyou, S. Hui and L. Dapeng, 2004. Depth estimation of 2-D magnetic anomalous sources by using euler deconvolution method. Am. J. Applied Sci., 1: 209-214. DIO: 10.3844/ajassp.2004.209.214

Gillette, D.A., 1999. A qualitative geophysical explanation for "hot spot" dust emitting source regions. Contrib. Atmosph. Phys., 72: 67-77.

Goudie, A.S. and N.J. Middleton, 2001. Saharan dust storms: Nature and consequences. Earth-Sci. Rev., 56: 179-204. DOI: 10.1016/S0012-8252(01)00067-8

Guerzoni, S. and R. Chester, 1996. The Impact of Desert Dust Across the Mediterranean. 1st Edn., Springer, USA., ISBN-10: 0792342941, pp: 406.

Harrison, S.P., K.E. Kohfeld, C. Roelandt and T. Claquin, 2001. The role of dust in climate changes today, at the last glacial maximum and in the future. Earth-Sci. Rev., 54: 43-80. DOI: 10.1016/S0012-8252(01)00041-1 
Haywood, J. and O. Boucher, 2000. Estimates of the direct and indirect radiative forcing due to tropospheric aerosols: A review. Rev. Geophys., 38: 513-543. DOI: 10.1029/1999RG000078

Jamal, P., M.Z. Alam, M. Ramlan. M. Salleh and M.M. Akib, 2005. Sewage treatment plant sludge: a source of potential microorganism for citric acid production. Am. J. Applied Sci., 2: 1236-1239. DOI: 10.3844/ajassp.2005.1236.1239

Karami, A., Z.A.M. Ahmad and K. Sijam, 2009. Morphological characteristics and pathogenicity of Synchytrium psophocarpi (Rac.) baumann associated with false rust on winged bean. Am. J. Applied Sci., 6: 1876-1879. DOI: 10.3844/ajassp.2009.1876.1879

Levin, Z., E. Ganor and V. Gladstein, 1996. The effects of desert particles coated with sulfate on rain formation in the eastern mediterranean. J. Appl. Meteorol., 35: 1511-1523. DOI: 10.1175/15200450(1996)035<1511:TEODPC> 2.0.CO;2

Moulin, C., 1998. Satellite climatology of African dust transport in the mediterranean atmosphere. J. Geophys. Res., 103: 13137-13143. DOI: 10.1029/98JD00171
Torres, O., P.K. Bhartia, J.R. Herman, A. Sinyuk and P. Ginoux et al., 2002. A long-term record of aerosol optical depth from TOMS observations and comparison to AERONET measurements. J. Atmosph. Sci., 59: 398-413. DOI: 10.1175/15200469(2002)059<0398:ALTROA>2.0.CO;2

Tucker, C.J. and S.E. Nicholson, 1999. Variations in the size of the Sahara Desert from 1980 to 1997. Ambio 28: 587-591.

Vernooy, J.H.J., M.A. Dentener, R.J. van Suylen, W.A. Buurman and E.F.M. Wouters, 2002. Longterm intratracheal lipopolysaccharide exposure in mice results in chronic lung inflammation and persistent pathology. Am. J. Respir. Cell Mol. Biol. 26: 152-159. PMID: 11751215

Wurzler, S., T.G. Reisin and Z. Levin, 2000. Modification of mineral dust particles by cloud processing and subsequent effects on drop size distributions, J. Geophys. Res., 105: 4501-4512. DOI: 10.1029/1999JD900980 